\title{
MORPHOLOGY OF SUPRAEPENDYMAL CELLS AND THEIR OCCURRENCE IN THE CEREBRAL VENTRICLES OF SHEEP AND GOATS. A SCANNING ELECTRON MICROSCOPY STUDY
}

\author{
V. RAJTOVÁ \\ Department of Anatomy and Histology, University of Veterinary Medicine, 04181 Košice, Slovakia \\ Received September 26, 1994 \\ Accepted March 30, 1995
}

\begin{abstract}
$\mathrm{R}$ a j t o v á V.: Morphology of Supraependymal Cells and their Occurrence in the Cerebral Ventricles of Sheep and Goats. A Scanning Electron Microscopy Study. Acta vet. Brno 1995, 64:17-21.

Occurrence and external morphology of supraependymal cells (SECs) were studied in 14 Merino sheep and 24 crossbred goats of both sexes. This type of supraependymal structures in both small ruminant species occurred only in the upper part of the third cerebral ventricle. In sheep they were recorded only during physiological estrus and gravidity in the recessus infundibuli. In male goats, the infundibular recessus surface was covered with SECs only during the mating period (autumn months) whereas in female goats they were present during all phases of the ovarian cycle but also after hormonal stimulation. On the surface of the eminentia mediana surface in goats (independent of sex) supraependymal cells occurred only in animals after gonadectomy. Occurrence of supraependymal cells in the third cerebral ventricle seems to be connected with the activity of the gonads, or their higher centres. Differences between sheep and goats were found in the structure of the external surface of the ependymal lining of the upper part of the third cerebral ventricle.
\end{abstract}

Central nervous system, ventriculus tertius, ependyma, sheep, goat

Structures found on the surface of the ependymal lining of the cerebral ventricles belong among its regional characteristics. They protrude into the ventricular lumen and are denoted as supraependymal structures to which supraependymal cells also belong. They were first discovered by K o $1 \mathrm{~m}$ e r (1921) using light microscopy, and later by electron microscopy in different locations of the cerebral ventricles, in numerous animal species $(\mathrm{Cl} \mathrm{e} \mathrm{m}$ e $\mathrm{n} \mathrm{t}$ and M a r i n i 1972; S c o t t et al. 1973, 1974; C o a t e s 1973ab; B r a w e r et al. 1974;

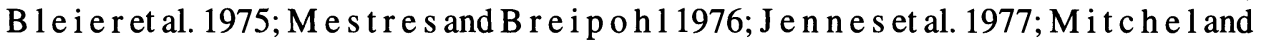
C a r d 1978). K o z l o w s k i et al. $(1972,1973)$ reported brief data on the supraependymal cells in sheep.

The present paper deals with the description of supraependymal cells in sheep and goats, to compare them, and then show differences between them.

\section{Materials and Methods}

Thirty eight animals, 14 Merino sheep and 24 crossbred goats of both sexes were used. The animals were divided in one control and two experimental groups. The control ewes were killed during the anestrous or estrous phases of the ovarian cycle, female goats in the period of anestrus, proestrus, estrus and luteal phase. One pregnant ewe and one goat (d 80 of pregnancy) were also included in the control group. Males of both species were killed during the "rest" period in April, and during the mating period (October, November).

In experimental group 1, hormone preparations were administered to adult experimental ewes and goats as follows:

During the anticipated period of estrus (April) hormone preparations: (40 $\mu$ g synthetic LH-RH together with $250 \mu \mathrm{g}$ synthetic Gn-RH, i.m., at 30 min intervals) were administered.

The same group of female goats was given $20 \mathrm{mg}$ synthetic progesterone in vaginal sponges. The animals were killed 26 hours after the last i.m. injection, or 16 days after insertion of vaginal sponges.

In experimental group 2, mature females and male goats were gonadectomized; artificial cryptorchids were made of two male goats. The animals of this group were killed 2 months following gonadectomy. Also one testicular hermaphrodite, acquired incidentally, was included in this group.

After exsanguination, the heads of all animals were rinsed in $0.2 \mathrm{~mol} / /$ phosphate buffer, preliminarily fixed by perfusion of Karnovsky solution. After the brains were removed, the samples were fixed using $3 \%$ glutaraldehyde solution in $0.2 \mathrm{~mol} / \mathrm{l}$ cacodylate buffer (the temperature of all solutions was $4^{\circ} \mathrm{C}$ ). After processing (M u ra k a m i et 
al. 1977) the samples were dried by the critical point method, coated with gold, and examined using the scanning electron microscope Stereoscan Cambridge 2A and Jeol.

\section{Results}

Generally, the supraependymal cells (SEC) were found in both species of small ruminants studied though only in the lower part of the third cerebral ventricle, and on its bottom (eminentia mediana).

\section{She e p}

In animals under study, SECs were only found in ewes in the period of physiological estrus and during gravidity ( Plate IV., Figs 1a, b). In other animals, no SECs were observed on the surface of the lower part of the third cerebral ventricle, neither in other stages of their reproductive cycle nor after hormonal stimulation. A similar finding, i.e. absence of SECs was also noted in rams.

In both aforementioned groups of ewes, the numbers of SECs were low. The cell bodies were predominantly oval, often covered with structures reminiscent of short cilia or microvilli. They formed 3-7 shorter, thin, and sometimes ramifying processes which (especially during gravidity) were terminated in ruffled membranes.

\section{Go at s}

In female goats during anestrus, in addition to great number of secretory protrusions in the typical infundibular recessus, ( Plate IV., Fig. 2) there were only sporadic SECs, with some of their processes forming ruffled membranes. In proestrus, from the recessus suprachiasmaticus to the recessus inframamillaris, abundant supraependymal cells covered the entire upper cilia-free part of the infundibulum. SECs had more radially arranged processes, ranging from spider-shaped to star-shaped appearance. These processes terminated in ruffled membranes. During estrus, the number of supraependymal cells decreased. Some of them did not differ from those of the previous period. Other SEC group, however, had a different external morphology. Cell their bodies were predominantly round and covered with hemispherical structures. Their processes were not apparent, because they were entirely hidden in the subependyma. This group of cells may be observed at various depths of the ependymal layer (Plate IV., Figs. 3a,b). In the luteal phase of the ovarian cycle, and in the 80-day pregnant goat, a lower number of supraependymal cells was recorded than in females during estrus or proestrus. Their external morphology differed only slightly from supraependymal cells found in proestrus.

In male goats, in the so-called period of "sex rest" (spring months), no supraependymal cells were found in the recessus, while during mating (autumn months) they were present, though only in lower numbers. Their external appearance did not differ from those found in female goats during estrus ( Plate V., Figs. 4a,b).

Administration of the synthetic LH-RH with Gn-RH induced, in addition to a lower number of secretory protrusions, formation of great numbers of supraependymal cells (as in proestrus). Administration of synthetic progesterone in the form of vaginal sponges induced almost the same picture on the surface of the lower part of the third cerebral ventricle as was that of physiological estrus (Plate V., Figs. 5a,b, 6a,b).

Two months after gonadectomies of females and males (Plate VI., Fig. 7), independent of sex prior to the operation, the structure of the ependymal lining of the infundibulum was reminiscent of that of the females during anestrus due to the presence of large numbers of secretory granules. Unlike in these, however, in gonadectomized animals there were greater numbers of SECs. Most of them formed ruffled membranes. The surface of many membranes was covered with hemispherical to spherical protrusions that have not been found in other groups of animals under study. 
In the testicular hermaphrodite we studied, in addition to abundant secretory protrusions, there were supraependymal cells which by their appearance and numbers, resembled those of females in proestrus. In addition to these, there were cells with thin, long projections connecting each other (Plate VI., Fig. 9) on the surface of the rostral part of the infundibulum. Their external morphology resembled nerve cells rather than supraependymal cells. In goat cryptorchids (Plate VI, Fig. 8) both appearance and number of SECs were similar to findings in females in proestrus.

The eminentia mediana epithelium of goats

No supraependymal cells were found on the eminentia mediana surface under physiological conditions and after hormonal stimulation. At this site, SECs did not occur until after gonadectomy both of females and males. Their external morphology as well as the amount were the same, independent of sex before the operation. Some of these cells were irregularly spherical, their body surface being covered with short cilia-like protrusions, or else they formed cytoplasmic lamellar protrusions which gave them a characteristic rosette-like appearance. The processes of this group of SECs were not clear. The second group of SECs had two or more short processes which formed ruffled membranes. Many SECs on the eminentia mediana surface emerged from deeper layers at sites of differently formed lacunas (Plate VI., Figs. 10a, b).

\section{Discussion}

Supraependymal cells, whose occurrence was also noted in both mature small ruminant species, are one form of supraependymal structures in the ventricular system of the central nervous system of vertebrates. According to C o a t e s (1973b), their findings in the cerebral ventricles are not an isolated phenomenon, dependent upon species, sex or age of animals. Our findings of these cells, however, have not completely confirmed this opinion, because their occurrence, mainly in sheep under physiological conditions, was to a certain degree, dependent upon sex, state of the ovarian cycle, and mating season. The ependymal epithelium of the third cerebral ventricle of sheep during various phases of the ovarian cycle, and after hormonal stimulation was studied by K o z l o w s k i et al. (1973) as well as Co a t e s and D a v i s $(1975,1977)$. These authors, however, have not referred to the presence of supraependymal cells, whereas we have noted them in our sheep material, but only among ewes during estrus and gravidity. In rams under physiological conditions, as well as in ewes after hormonal stimulation, supraependymal cells were absent from the surface of the cerebral ventricles.

In control goats, unlike in sheep, the supraependymal cells always occurred on the surface of the infundibular recessus, but their numbers changed, depending upon the physiological status of the ovarian cycle. Males out of mating season (spring months), when supraependymal cells were not evident, were an exception. In the autumn months (i.e. the period when also the reproductive cycle of females culminates) besides the typical supraependymal cells with processes forming ruffled membranes, there were also cells detected whose projections were hidden in the subependyma, and the entire surface of their body was covered with hemispherical protrusions. The same cells were also found in female goats after hormonal stimulation, but also two months after gonadectomy, independently of sex before the operation. One exception was the testicular hermaphrodite, in which apart from greater numbers of typical supraependymal cells, characteristic of females during proestrus, there were numerous neuron-like cells with long, thin protrusions connecting with each other and forming a network. The appearance of the latter is similar to cells reported by M i t c h e 11 and C a r d (1978) in a guinea-pig classified as neuron-like cells, but which in a macaque, C o a t e s (1973ab; 1975) classified 
as the first type of supraependymal cells. Thus, it would follow that even if the external morphology of the sexual organs indicated an incompletely developed male, the structure of the infundibular epithelial surface was typically female. It can be only supposed that some endocrine glands or the hypothalamic nuclei participating in the control of sexual functions in this animal were female-oriented. The alternative male/female type of behaviour of this animal as reported by its owner, seems to support our conclusions.

A different question is the presence or absence of supraependymal cells at the bottom of the third cerebral ventricle, the eminentia mediana. Of all animals used the occurrence of supraependymal cells on its surface was recorded only in animals two months after gonadectomy but never under physiological conditions or after hormonal stimulation. Their appearance differed from previously presented cells. One cell group had almost round bodies, however, without discernible processes. The body surface was covered with cilia-like protrusions. This group of cells represents according to $\mathrm{M} \mathrm{e}$ s t r e s and B r e i p o h l (1976) a phagocytic form of supraependymal cells. Another group has two or more processes transformed into ruffled membranes. These cells have therefore a polymorphic appearance. It is undoubtedly an example of a migrating cell type.

The function of supraependymal cells, as well as that of other supraependymal structures, has not been satisfactorily elucidated, even if their phagocytic capacity has been confirmed.

Supraependymal cells studied in our material in sheep and goats were not present in the entire ventricular system of the brain. They were localized only in the upper part of the third cerebral ventricle, and on the eminentia mediana. Their numbers, their relationship to gonad activity in both sexes, as well as their polymorphic appearance, were always more pronounced in goats than in sheep. In both small ruminant species, SECs were not present (or quite sporadically) when the ependyma in the upper part of the third cerebral ventricle was active in secretion. On the other hand, their numbers increased with any decrease in ependymosecretion. Gonadectomized goats, in which, along with secretory protrusions, there were large numbers of SECs, were an exception. This finding leads us to the following speculation: after gonadectomy any connection to the long-term feedback mechanism axis is interrupted. Therefore, probably, through short-term feedback, receptors in the hypothalamus and in the anterior pituitary are stimulated to produce tropic sex hormones which, however, due to absence of gonads have no possibility to function. We suppose that it is the large number of macrophage-like supraependymal cells on the eminentia mediana surface that is involved in balancing (or removal) of certain specific compounds.

\section{Morfológia a výskyt supraependymových buniek v mozgových komorách ovce a kozy. Stúdium v riadkovacom elektronovom mikroskope}

Na 14 ovciach plemena Merino a 24 krížencoch kozy obojeho pohlavia sme sledovali a porovnávali výskyt a vonkajšiu morfológiu supraependymových buniek. Táto forma supraependymových štruktúr u obidvoch malých prežúvavcov sa vyskytuje len v dolnej časti tretej mozgovej komory. $U$ oviec sme ich zaznamenali iba počas fyziologického estru a gravidity $\mathrm{v}$ recessus infundibuli. U samcov kôz pokrývali povrch infundibulárneho recessu len v období pripústania (jesenné mesiace), zatialčo u samíc kozy boli na uvedenom mieste prítomné počas všetkých fáz ovariálneho cyklu, ale aj po hormonálnej stimulácii. Na povrchu eminentia mediana kôz (nezávisle od pohlavia) sa nachádzali supraependymové bunky $\mathrm{u}$ jedincov iba po gonadektómii. $\mathrm{V}$ práci sa dáva výskyt supraependymových buniek $\mathrm{v}$ tretej mozgovoej komore do súvislosti s činnostou gonád, resp. ich nadradených centier. Zistili sa rozdiely v stavbe vonkajšieho povrchu ependymovej výstielky dolnej casti tretej mozgovej komory medzi ovcou a kozou. 


\section{References}

BLEIER R., ALBRECHT R., CRUCE J.A.F. 1975: Supraependymal cells of hypothalamic third ventricle: identification as resistant phagocytes of the brain. Science 189:299-301

BRAWER J.R., LIN P.S., SONNENSCHEIN C. 1974: Morphological plasticity in the wall of the third ventricle durig the estrus cycle in the rat: A scanning electron microscopic study. Anat. Rec. 173:481-490

CLEMENTI F., MARINI D. 1972: The surface of the walls of cerebral ventricles and chorioidal plexus in cat. $Z$. Zellforsch. 123:82-95

COATES P.W. 1973a: Supraependymal cells and surface specializations on the floor of monkey third ventricle: Scanning electron microscope studies. Anat. Rec. 175:294 (Abstract)

COATES P.W. 1973b: Supraependymal cells in recesses of the monkey third ventricle. Amer. J. Anat. 136: 533-539

COATES P.W., DAVIS S.L. 1977: The sheep third ventricle: A scanning electron microscopy of estrus and estrogen-progesterone treated anestrous ewes. Biol. Reprod. 17:567-573

JENNES L., SIKORA K., SIMONSBERGER P., ADAM H. 1977: Ventriculäre Topographie des Diencephalen Ependyms bei Rattus rattus (L.) - eine REM Untersuchung. J. Hirnforsch. 18:501-520

KOLMER V. 1921: Über eine einartige Beziehung von Wanderzellen zu den Chorioidplexus der Wirbeltieres. Anat. Anz. 54:15-19

KOZLOWSKI G.P., SCOTT D.E., MURPHY J.A. 1972: Scanning electron microcsopy of the lateral ventricles of sheep. Am. J. Anat. 135:561-566.

KOZLOWSKI G.P., SCOTT D.E., KROBISH-DUDLEY G. 1973: Scanning electron microscopy of the third ventricle of sheep. Z. Zellforsch. 136:169-176

MESTRESS P., BREIPOHL W. 1976: Morphology and distribution of supraependymal cells in the third ventricle of the albino rat. Cell. Tissue Res. 168:303-314

MITCHELL L.A., CARD J.P.: Supraependymal neurons overlaying the periventricular region of the third ventricle of the guinea-pig: A correlative transmission electron microscopic study. Anat. Rec. 192:441-458

MURAKAMI T., YAMAMOTO K., ITOSHIMA T. 1977: Modified tanin-osmium conductive staining method for non-coated SEM specimens and application to microsection SEM of spleen. Arch. histol. jap. 40:35-40

SCOTT D.E., KOZLOWSKI G.P., KROBISH-DUDLEY G. 1973: A comparative ultrastructural analysis of the third cerebral ventricle of the north american mink (Mustela vison). Anat. Rec. 175:155-168

SCOTT D.E., KOZLOWSKI G.P., SHERIDAN M.N. 1974: Scanning electron microscopy in the ultrastructural analysis of the mammalian cerebral ventricular system. Int. Rev. Cytol. 87:349-388 
Rajtová V.: Morphology...pp. 17-21.

Plate IV.
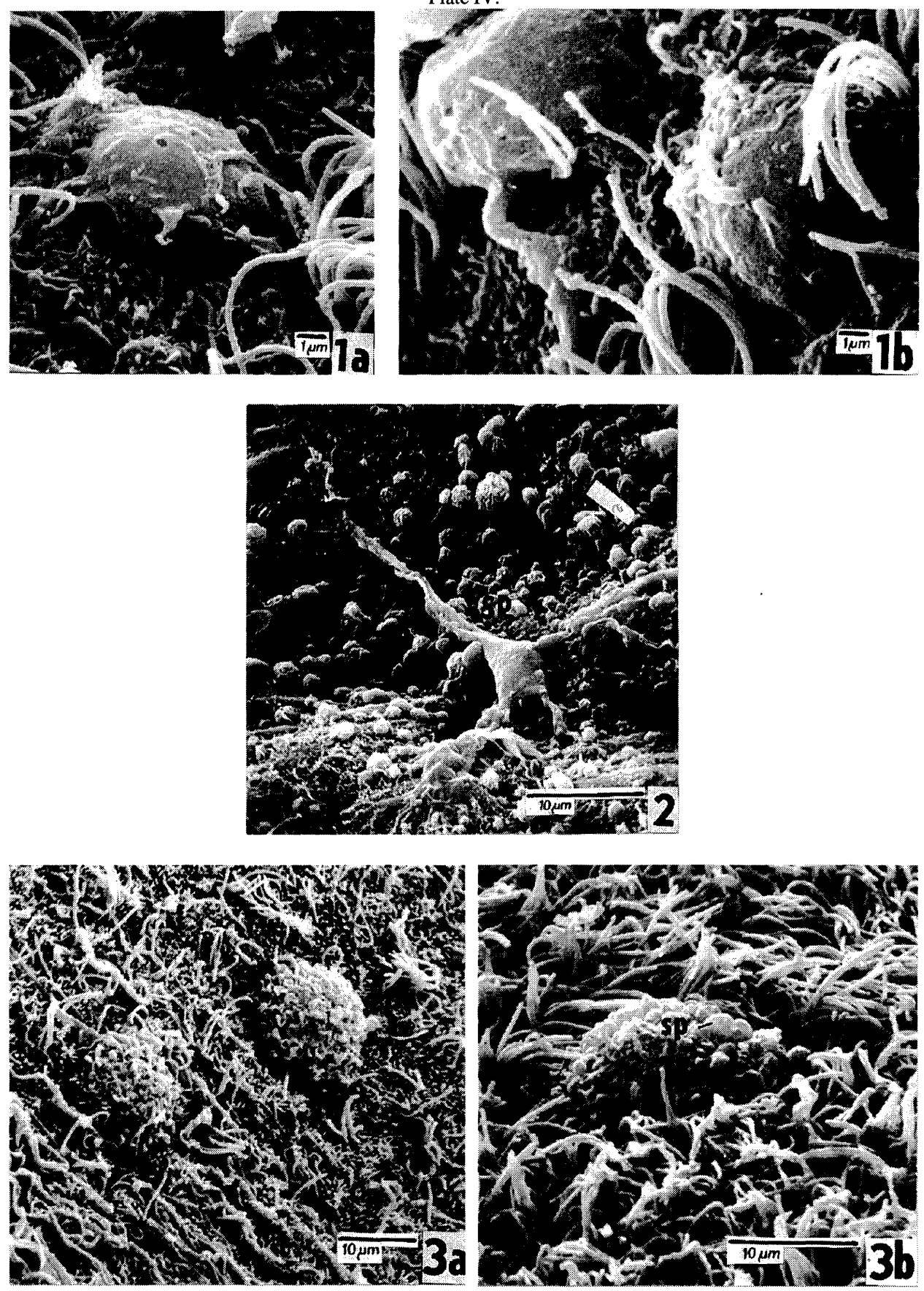

Fig. 1a, 1b: Supraependymal cells from the infundibular recess of the ewe, estrus. x 5500 .

Fig. 2: One isolated supraependymal cell from the surface of the infundibular recess in the female goat, anestrus. $\times 2300$.

Fig. 3a, 3b: Supraependymal cells from the recessus infundibuli of a female goat, estrus. Two types of cells with embedded projections in the subependyma (3a) and migrating cell (3b). x 1300 (a), x 2300 (b). 
Plate V.
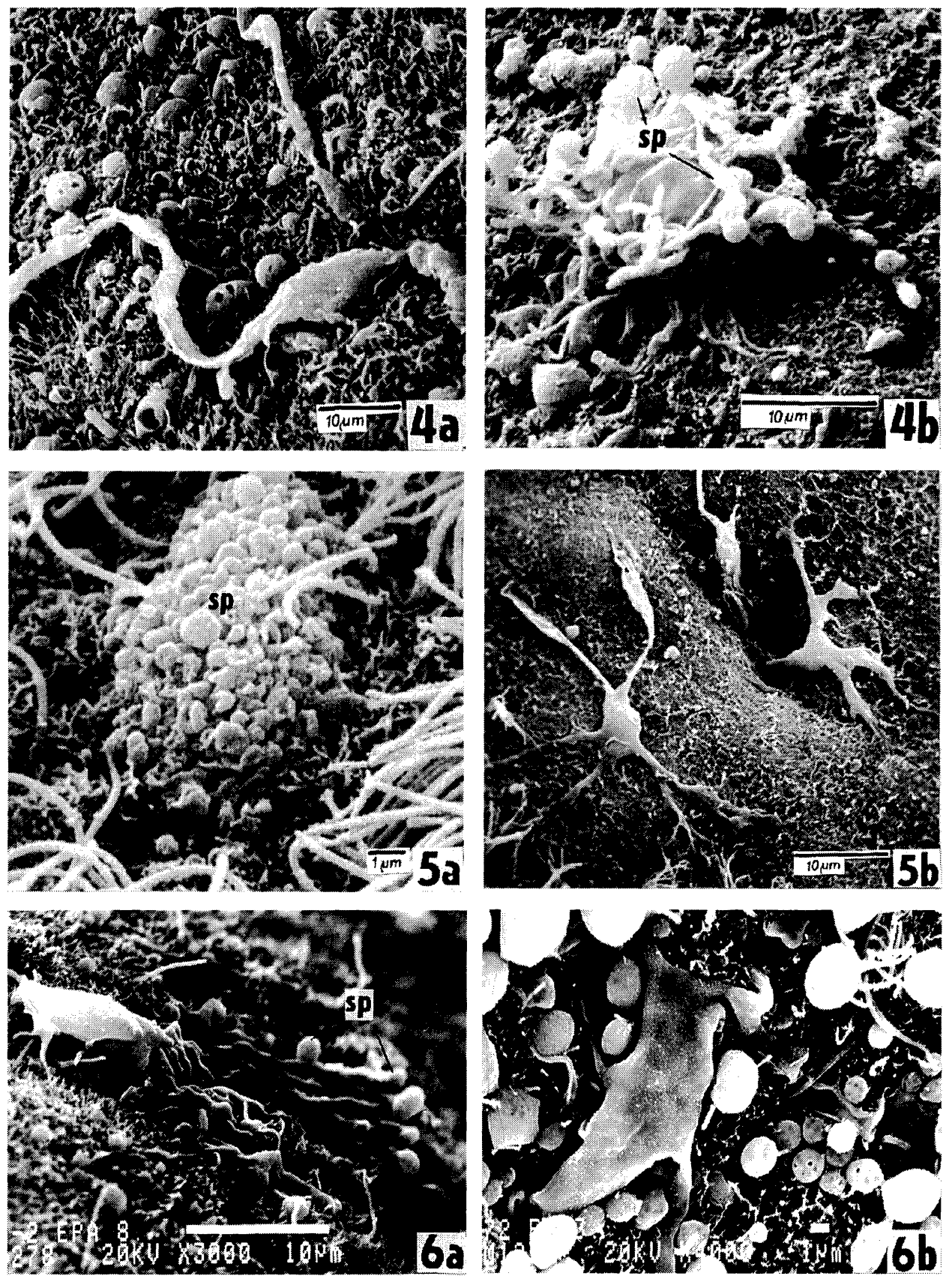

Fig. 4a, 4b: Supraependymal cells of the infundibular recess of the male goat during the mating period (October, November). x 1300 (a), x 2500 (b).

Fig. 5a. 5b: Two types of supraependymal cells from the surface of the infundibular recess of the female goat $16 \mathrm{~d}$ after administration of synthetic progesterone using vaginal sponges. x 5600 (a), x 1800 (b).

Fig. 6a, 6b: Supraependymal cells from the recessus infundibuli in the female goat two months after gonadectomy. The presence of spherical and hemispherical protrusions is characterisctic on the ependymal surface and also on the ruffled membranes. x 3000 (a), x 4000 (b) 

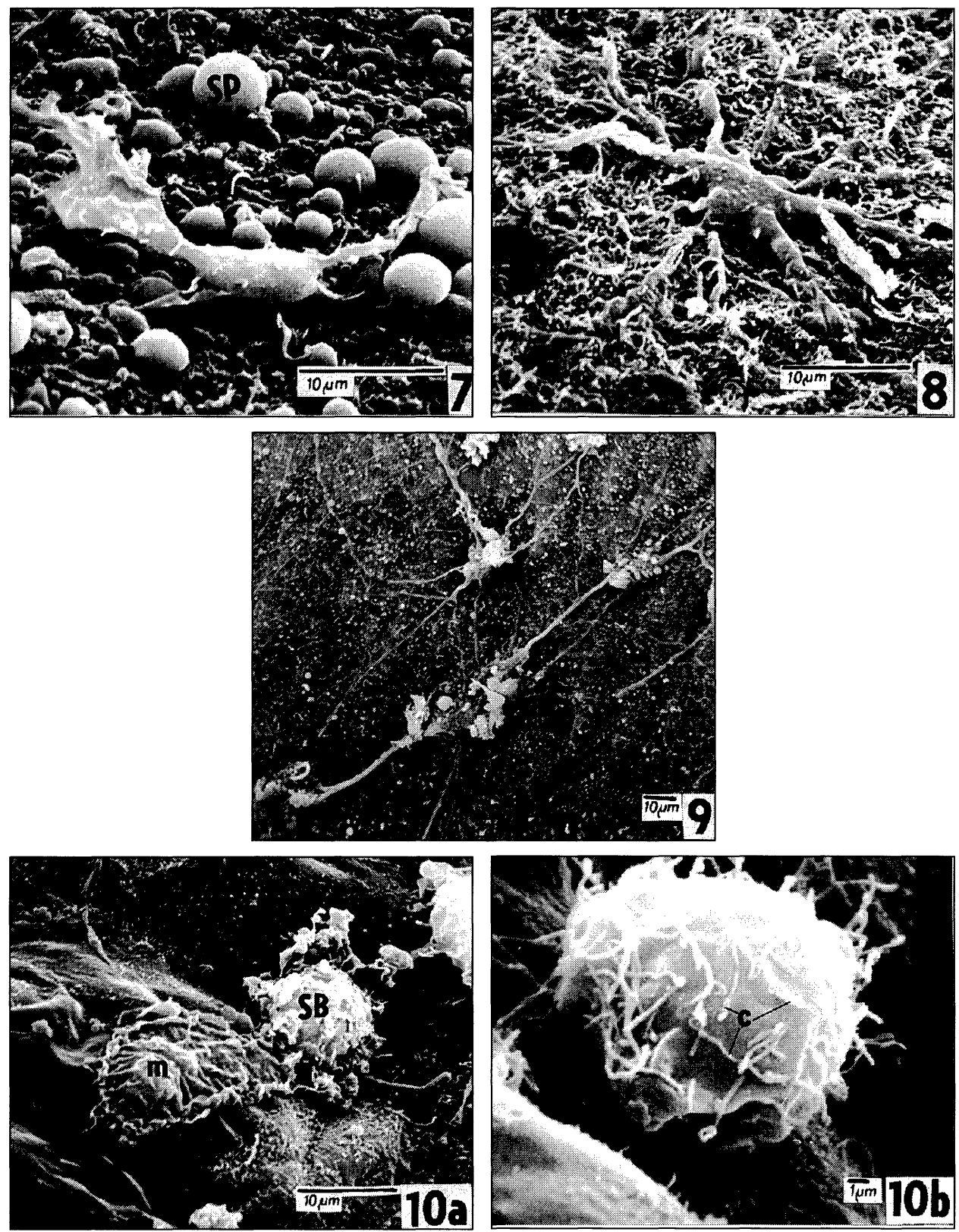

Fig. 7: A part of the infundibular surface with one supraependymal cells in the male goat two months after gonadectomy. x 2700.

Fig. 8: One supraependymal cell from the infundibular recess in the artifical cryptorchid of the goat. $x 2500$.

Fig. 9. A group of neuron-like cells on the infundibular surface of the testicular hermaphrodite goat. The narrow and branching projections form a network. $\mathrm{x} 4500$.

Fig. 10a, 10b: Two of many supraependymal cells on the surface of the median eminence of the goat, two months after gonadectomy. x 1700 (a), x 4000 (b).

$\mathrm{c}$ - cilia-like projections, $\mathrm{m}$ - ruffled membranes, sp- hemispherical protrusions on the surface of the body or ruffled membrane of supraependymal cells, SB - supraependymal cells, SP - spherical protrusions, V - supraependymal fibre 